Acta Universitatis

Nicolai Copernici

Zabytkoznawstwo i Konserwatorstwo XLII, Toruń 2011

\author{
Alicja Jagielska-Burduk \\ Uniwersytet Kazimierza Wielkiego w Bydgoszczy \\ Dariusz Markowski \\ Zakład Konserwacji i Restauracji Sztuki Nowoczesnej UMK
}

\title{
O lwowskich zbiorach Bolesława Orzechowicza
}

T wowska Galeria Sztuki (do 1998 roku Lwowska Galeria Obrazów) to

jjedno z największych muzeów we Lwowie, przechowujące około 50 tys. eksponatów. Powstało ono z przedwojennej miejskiej galerii obrazów oraz włączonych do niej w okresie radzieckiej okupacji Lwowa innych galerii, a także zbiorów kościelnych i prywatnych. Miejska galeria obrazów została utworzona w 1897 roku na mocy decyzji magistratu lwowskiego. Ważne daty w jej historii to rok 1907, w którym zakupiono dużą kolekcję Jana Jakowicza (około 400 obrazów, w tym dzieła Rafaela, Rembrandta, Rubensa, van Dycka, Velázqueza, Ribeiry, Watteau i innych), oraz rok 1919, kiedy powiększono ją o podarowany miastu zbiór Bolesława Orzechowicza (il. 1) (broń, zegarki francuskie oraz malarstwo i rzemiosło artystyczne). Galeria obrazów miała wówczas trzy oddziały: sztuki polskiej, sztuki zachodnioeuropejskiej oraz Panorama Racławicka. W 1938 roku swe kolekcje przekazali galerii Leon Piniński i Konstanty Brunicki.

Dzieła ofiarowane przez Bolesława Orzechowicza na uroczystym posiedzeniu Rady Miejskiej w dniu 28 sierpnia 1919 roku miały szczególne znaczenie dla galerii malarstwa, gdyż oprócz portretów rodów Rozwadowskich i Orzechowiczów znalazły się wśród nich prace wybitnych artystów polskich: Henryka Rodakowskiego, Leopolda Loefflera, Stanisława 
Chlebowskiego, Artura Grottgera, Jana Matejki, Henryka Siemiradzkiego, Józefa Brandta, Alfreda Wierusza-Kowalskiego, Jacka Malczewskiego, Teodora Axentowicza, Stanisława Wyspiańskiego, Witolda Pruszkowskiego, Piotra Michałowskiego, Juliusza i Wojciecha Kossaków, Władysława Bakałowicza, Aleksandra Kotsisa, Włodzimierza Tetmajera, Juliana Fałata oraz Jana Stanisławskiego.

Tajemnicze, bo nieprzedstawione we współczesnej literaturze, a dodatkowo szczególnie interesujące $\mathrm{w}$ dobie międzynarodowej dyskusji o nowych koncepcjach własności zabytków, pozostają losy wspomnianej kolekcji dzieł sztuki Bolesława Orzechowicza. Analizę jej losów poprzedzi omówienie najważniejszych momentów życia ofiarodawcy oraz podejmowanej przez niego działalności społecznej.

Jędrzej Orzechowicz, ojciec Bolesława, był znanym lwowskim lekarzem, a matka Zofia wywodziła się ze znanych rodów Obniskich i Sierakowskich ${ }^{1}$. Dom Orzechowiczów we Lwowie uważano za miejsce spotkań kulturalnych i naukowych, a niejednokrotnie także debiutów polskich artystów ${ }^{2}$. Dorastając w atmosferze szacunku dla kultury i nauki polskiej, Bolesław Orzechowicz ukończył studia prawnicze we Lwowie oraz rolnicze w Hochenheim. Następnie podjął pracę w rodzinnym majątku w Kalnikowie pod Przemyślem. Stworzył tutaj cenne prywatne muzeum, w skład którego, oprócz dzieł sztuki zakupionych podczas licznych podróży zagranicznych, wchodziły przedmioty odziedziczone po rodzinie Rozwadowskich oraz Obniskich.

Bolesław Orzechowicz, poza darowaniem swych zbiorów lwowskiej galerii, od 1914 roku regularnie wspierał również działalność Towarzystwa na rzecz Nauki Polskiej (późniejsze Towarzystwo Naukowe we Lwowie), tworząc fundusze uzupełniające lub osobne dla uczczenia zmarłych rodziców - Jędrzeja i Zofii Orzechowiczów, oraz żony Wandy z Rozwadowskich ${ }^{3}$. Polscy przedstawiciele nauki uwiecznili jego zasługi, wydając w 1916 roku poświęconą mu dwutomową księgę pamiątkową. s. $276-277$.

1 Polski stownik biograficzny, t. 24, Wrocław-Warszawa-Kraków-Gdańsk 1979,

2 K. Badecki, Bolestaw Orzechowicæ: Sylwetka okolicznościowa, Lwów 1923, s. 6-7.

3 Dokumenty odnoszące się do fundacyj Bolesława Orzechowicza, [w:] Ksiegaa pamiatkowa ku czci Bolestawa Orzechowicza, Lwów 1916, s. XI-XXIII. 
Jak już wspomniano, w 1919 roku miejska galeria obrazów we Lwowie powiększyła się o przekazane przez Orzechowicza, zgromadzone przez niego zbiory sztuki, w tym kolekcję broni, obrazów oraz zegarków (łącznie 998 przedmiotów). Jako wyraz wdzięczności społeczeństwa za złożony dar w dniu 15 września 1921 roku Rada Miasta podjęła uchwałę o uznaniu Bolesława Orzechowicza za honorowego obywatela miasta Lwowa. Z tej okazji oraz aby uczcić otwarcie zbiorów dla szerszej publiczności, zorganizowano wystawę. Działalność Bolesława Orzechowicza wspierającego rozwój nauki została doceniona raz jeszcze 11 grudnia 1923 roku, kiedy to nadano mu tytuł doktora honoris causa Wydziału Prawa i Umiejętności Politycznych Uniwersytetu Jana Kazimierza we Lwowie. Podczas tej uroczystości Orzechowicza opisał najtrafniej Juliusz Makarewicz:

\begin{abstract}
Twoje imię należy już do historii narodu polskiego, do dziejów kultury i nauki polskiej, jako jej pomnożyciela. Nazwisko Twe zapisano już na karcie historii złotemi głoskami obok Ossolińskich, Czartoryskich, Lubomirskich, Dzieduszyckich i tylu innych wielkodusznych fundatorów, mecenasów sztuki i nauki. Gdy poprzednicy Twoi dzieła wielkie i piękne powoływali do życia, ofiarowując na ten cel fragment magnackiej fortuny, zazwyczaj z myślą zdobycia dla rodziny jeszcze wyższego w społeczeństwie stanowiska, Ty działałeś inaczej, poświęcałeś fortunę średnią, a dary swe uzupełniałeś dochodami zdobywanemi własną pracą i zabiegliwością, a działałeś zawsze bez zwracania na siebie uwagi, skromnie, pocichu, niemalże tajemniczo ${ }^{4}$.
\end{abstract}

Ciekawą rolę w dokumentowaniu życia Bolesława Orzechowicza odegrał Rudolf Mękicki - historyk sztuki, muzeolog, medalier i heraldyk. Nawiązując do bogatej roślinności Kresów Wschodnich, wykonał on między innymi dyplom nadania Bolesławowi Orzechowiczowi honorowego obywatelstwa królewskiego stołecznego miasta Lwowa. Bardzo interesujące jest także rozesłane przez Prezydium Rady Miasta zaproszenie na otwarcie wystawy zorganizowanej z okazji przekazania miastu przez Orze-

4 Przemówienie Jego Magnificencji Rektora prof. dr. Juljusza Makarewicza, [w:] K. Badecki, Bolesław Orzechowicz, honorowym doktorem praw Uniwersytetu Jana Kazimierza, Lwów 1924, s. 28. 
chowicza należącej do niego kolekcji sztuki ${ }^{5}$. Artysta przedstawił na nim wszystkie najważniejsze składniki daru, począwszy od zbioru polskiego i obcego malarstwa, przez zegarki, do zbioru broni' (il. 4). Rudolf Mękicki był także autorem exlibrisu oraz winiety do rozdziałów w książce Bolesław Orzechowicz, honorowym doktorem praw Uniwersytetu Jana Kazimierza.

Powracając do zasadniczego tematu - losów darowizny Bolesława Orzechowicza, warto przedstawić okoliczności złożenia daru oraz jego składniki. Przed ostatecznym zawarciem umowy darowizny kolekcja została przekazana w 1915 roku pod opiekę gminy miasta Lwowa. Działania wojenne prowadzone w okolicach Kalnikowa, gdzie zbiory dotąd przechowywano, spowodowały, że w obawie przed możliwymi zniszczeniami Bolesław Orzechowicz zwrócił się do miasta z prośbą o ich zabezpieczenie 7 . W dniu 16 sierpnia 1919 roku została zawarta oficjalna umowa między Bolesławem Orzechowiczem i jego prawnikiem Leonardem Tarnawskim a przedstawicielami gminy miasta Lwowa Marcelim Chlamtaczem oraz Aleksandrem Czołowskim ${ }^{8}$. Już w pierwszych zdaniach dokumentu zaakcentowano polskość zbiorów, darczyńca wyrażanie swej woli rozpoczął bowiem od słów: „Uważając Lwów za ostoję polskości, której szczególny złożył dowód, tocząc z Ukraińcami zacięte boje o przynależność do Polski” (il. 2). W takiej atmosferze Bolesław Orzechowicz postanowił przekazać gminie miasta Lwów „wszystkie swe zbiory artystyczne i starożytne, a mianowicie: galerję obrazów, sztychy, rzeźby, odlewy, miniatury, meble o wartości muzealnej, zbiór broni starożytnej, zbiór szkła i porcelany". Zgodnie $z$ art. II zbiory te miały stanowić po wieczne czasy niepodzielną całość oraz przyjąć nazwę „Zbiory Bolesława Orzechowicza”. Pieczę nad prawidłowym wykonaniem umowy miała sprawować Kuratoria (pisownia oryginalna: Kuratorya), w skład której wchodzili m.in. profesor Uniwersytetu Jana Kazimierza Oswald Balzer oraz wiceprezydent

5 K. Badecki, Zbiory Bolestawa Orzechowicza, Lwów 1922, s. XV.

6 Zaproszenie na wystawę ofiarowanych gminie m. Lwowa zbiorów Bolesława Orzechowicza, Centralne Państwowe Archiwum Historyczne Ukrainy we Lwowie, zespół 74, opis 1, jednostka 5, k. 33.

7 K. Badecki, Zbiory Bolestawa Orzechowicza, s. IX-X.

8 Umowa o darowiznę z dnia 16 sierpnia 1919 r., Centralne Państwowe Archiwum Historyczne Ukrainy we Lwowie, zespół 74, opis 1, jednostka 1, k. 1-2. 
Lwowa Marceli Chlamtacz. Zastrzeżenie możliwości odwołania darowizny przez ofiarodawcę, a po jego śmierci przez członków Kuratorii zawarto w art. VI. Nawiązując do zacytowanej wyżej myśli przewodniej tekstu umowy, jako przesłankę podjęcia decyzji o cofnięciu darowizny wskazano trwałą utratę charakteru polskiego Lwowa na skutek zdarzeń politycznych lub społecznych. Z kolei art. VIII dokumentu stwierdzał, że w razie odwołania darowizny zbiory miały znaleźć się na Wawelu, a gdyby okazało się to trudne do wykonania, Kuratoria miała zdecydować o przekazaniu ich do Warszawy, Wilna, Poznania lub Gdańska (il. 3).

Wyszczególnione w umowie darowizny obowiązki gminy miasta Lwowa miały polegać m.in. na umieszczeniu zbiorów w przeznaczonych do tego pomieszczeniach pałacu Lozińskiego, zapewnieniu opieki specjalistów, poddawaniu obiektów czynnościom zmierzającym do ich zachowania oraz udostępnieniu społeczeństwu. Treść umowy i wynikające z niej powinności dla miasta Lwowa były także dyskutowane podczas posiedzenia Rady Miejskiej. Odniesiono się wówczas do zastrzeżenia jedności zbiorów: „Jakkolwiek zasadniczy warunek, że zbiory te maja po wieczne czasy tworzyć odrębną, nierozdzielną całość - jest pod wieloma względami uciążliwy - mimo to, ze względu na ich niezwykła wartość, nie może być brany w rachubę" ". Po raz ostatni kolekcja została wzbogacona w związku z ostatnią wolą Bolesława Orzechowicza, wyrażoną w testamencie spisanym na kilka miesięcy przed jego śmiercią. W punkcie IX testamentu przewidziano, że zbiorom Orzechowicza testator przekazuje niektóre elementy wyposażenia domu we Lwowie oraz w Kalnikowie ${ }^{10}$.

Obecnie, po ponad 90 latach od momentu zawarcia umowy darowizny, zbiory sa rozproszone. Kilka obrazów autorstwa Iwana Trusza trafiło np. do Muzeum Narodowego we Lwowie, gdzie zostały przeniesione ze względu na swą tematykę ukraińską. Ostatnio poddano je zabiegom konserwatorskim i zaprezentowano publicznie podczas wystawy poświęconej ich twórcy. Najprawdopodobniej pozostała część kolekcji

9 Sprawozdanie z obrad Rady Miejskiej, Archiwum Państwowe Ukrainy we Lwowie, zespół 74, opis 1, jednostka 5, k. 191-192.

10 Odpis wierzytelny. Testament z dnia 31 lipca 1927 r., Archiwum Państwowe Ukrainy we Lwowie, zespół 74, opis 1, jednostka 2, k. 3. 
znajduje się w Lwowskiej Galerii Sztuki (dawniej Lwowskiej Galerii Obrazów). Dokładne ustalenie liczby obiektów pochodzących z daru Bolesława Orzechowicza byłoby możliwe po wnikliwym przestudiowaniu ksiag inwentarza. W salach dostępnych dla zwiedzających są wystawione niektóre eksponaty należące do tej kolekcji, m.in.: Portret Stanisława Augusta Poniatowskiego Marcella Bacciarellego, Bachantka Witolda Pruszkowskiego, Chrystus przed Pitatem Jacka Malczewskiego (il. 6) oraz scena Za praykeładem bogów Henryka Siemiradzkiego. Polsce, a dokładnie Muzeum Narodowemu we Wrocławiu, przekazano w 1946 roku zbiór rysunków Poczet Królón i Ksiażat Polskich wykonanych przez Jana Matejkę na zamówienie Maurycego Perles. Odnosząc status quo do zapisów umowy darowizny, obiekty pochodzące ze zbiorów Orzechowicza nie są ani eksponowane łącznie, ani też w żaden inny sposób wyodrębnione. Na uznanie zasługuje jednak fakt, że obrazy z kolekcji pojawiły się podczas organizowanych w Polsce wystaw, m.in.: „Twórczość Jacka Malczewskiego w zbiorach Lwowskiej Galerii Sztuki” w 2002 roku, „Arcydzieła malarstwa polskiego w zbiorach Lwowskiej Galerii Sztuki” w 2003 roku czy „Pejzaż malarzy polskich w zbiorach Lwowskiej Galerii Sztuki” w 2004 roku, dzięki czemu istniała możliwość zobaczenia mało znanych dzieł twórców polskich. Współorganizatorem wszystkich wspomnianych wystaw była Państwowa Galeria Sztuki w Sopocie.

Analiza statusu prawnego zbiorów jest trudniejsza, zagadnienie to można bowiem rozpatrywać na dwóch płaszczyznach - międzynarodowoprawnej oraz cywilnoprawnej. Podczas spisywania umowy nie obowiązywało na terenie Lwowa żadne polskie prawo stanowione, posługiwano się więc uregulowaniami państw zaborczych, a dokładnie - austriackim Allgemeines Bürgerliches Gesetzbuch (ABGB). Należałoby zatem nie tylko odnieść się do przepisów ABGB, ale też ustalić ich dokładną treść na dzień sporządzania umowy i ewentualne zmiany. Już w tym miejscu trzeba zaznaczyć, że skoro w dokumencie zastrzeżono możliwość odwołania darowizny, wskazując konkretny przypadek utraty przez miasto Lwów charakteru polskiego, zarówno za życia, jak i po śmierci darczyńcy, było to prawnie dopuszczalne. W źródłach archiwalnych są dostępne jedynie materiały pochodzące z posiedzenia Kuratorii Zbiorów Bolesława Orzechowicza, które odbyło się 26 września 1928 roku, w niecały rok po 
śmierci darczyńcy ${ }^{11}$. Brakuje natomiast informacji o późniejszych działaniach Kuratorii. Zagadnieniem, które warto poruszyć, jest ciagłość istnienia miasta Lwowa oraz jego autonomicznych władz. W tym stanie rzeczy, gdyby darowizna nie została odwołana, a zbiorów nie przekazano by do Polski, to obowiązki nałożone na miasto wynikające z omawianej umowy przeszły na jego sukcesora - czyli miasto ukraińskie Lwów. Warto dodać, że w 1939 roku, krótko po włączeniu ziem wschodnich do Ukrainy, wydano dekrety o nacjonalizacji przemysłu, banków oraz majątków ziemskich należących do Kościoła, właścicieli ziemskich i urzędników państwowych. Dodatkowo utrudnia to więc określenie statusu prawnego zbiorów ${ }^{12}$. Co prawda, kolekcja Orzechowicza już wcześniej stanowiła własność państwowa, tyle że państwa polskiego, dlatego problematyka nacjonalizacji ma większy wpływ na ustalanie podstaw prawnych bytu zbiorów znajdujacych się w posiadaniu chociażby osób prywatnych.

Po II wojnie światowej w wyniku ustalenia nowych granic Lwów znalazł się poza Polską. Dlatego też na problem zbiorów Bolesława Orzechowicza, których polskość była wielokrotnie podkreślana, trzeba także patrzeć pod kątem repatriacji, czyli powrotu dzieł do kraju macierzystego. Kwestia zmian politycznych na mapie Europy wydaje się w tym przypadku najważniejsza. Dodatkowo fakt przenoszenia się ludności polskiej z przypisanych Ukrainie terytoriów wyraźnie wskazuje na utratę przez ziemie na wschodzie charakteru polskiego. Dlatego w tym miejscu należy odwołać się do treści umów zawartych przez Polski Komitet Wyzwolenia Narodowego z trzema republikami radzieckimi, w tym z Ukrainą w 1944 roku - układ pomiędzy Polskim Komitetem Wyzwolenia Narodowego a Rządem Ukraińskiej Socjalistycznej Republiki Rad dotyczacy ewakuacji obywateli polskich z terytorium USRR i ludności ukraińskiej z terytorium Polski. Umowy dotyczyły głównie zagadnienia granic, przesiedleń, a jedynie pobieżnie traktowały o dobrach kultury. Zezwalały ewakuowanym na wywóz dzieł

11 Z posiedzenia Kuratorii Zbiorów Bolesława Orzechowicza w dniu 26 września 1928 r., Archiwum Państwowe Ukrainy we Lwowie, zespół 74, opis 1, jednostka 5, k. 175-177.

12 S. Kot, Problem restytucji dóbr kultury w przestrzeni postradzieckiej (na prayktadzie Ukrainy), [w:] Dobra kultury i problemy własności. Doświadczenia Europy Środkowej po 1989 roku, pod red. G. Czubek, P. Kosiewskiego, Warszawa 2005, s. 206. 
sztuki, jeżeli stanowiły one ich własność, a w przypadku majątku Kościoła upoważniały księży do zabrania ze sobą wyposażenia kościoła i przedmiotów kultu ${ }^{13}$. Mimo że przygotowywano układ regulujący w szerszym zakresie wymianę dóbr kultury, to nigdy nie został on zawarty ${ }^{14}$. Prowadzone po wojnie negocjacje dotyczące m.in. zbiorów biblioteki Ossolineum zakończyły się przekazaniem jedynie pojedynczych obiektów ${ }^{15}$. Duży wpływ na obecne stosunki kulturalne polsko-ukraińskie ma umowa z 1992 roku, która stanowi podstawę współpracy w zakresie ochrony, scalania i ujawniania dziedzictwa kultury oraz ułatwiania dostępu do niego. Strony ustaliły w niej, że repatriacja ma odnosić się tylko do pojedynczych przedmiotów o wyjątkowym znaczeniu dla dziedzictwa narodowego ${ }^{16}$.

W tle problematyki repatriacji i dyskusji na temat wzajemnych roszczeń poszczególnych krajów pojawiają się główne koncepcje postrzegania zabytków. Najpopularniejsza, bo zawarta w wielu konwencjach międzynarodowych, jest idea wspólnego dziedzictwa kultury. Stanowi ona podstawę współdziałania państw w zakresie ochrony zabytków na arenie międzynarodowej i została między innymi wykorzystana w Konwencji o ochronie dóbr kulturalnych w razie konfliktu zbrojnego ${ }^{17}$. Jej zwolennicy zakładaja, że na zabytki trzeba patrzeć przez pryzmat całości dorobku ludzkości, a państwa jako podmioty występujące w stosunkach międzynarodowych powinny działać na rzecz ochrony zabytków w imieniu całej cywilizacji oraz uczestniczyć w niej w przestrzeni całego świata ${ }^{18}$. Nieco inaczej byt zabytku traktuje koncepcja skoncentrowana na obiekcie i jego zachowa-

13 W. Kowalski, Repatriacja dóbr kultury w sytuacji cesji terytorialnej i rozpadu państw wielonarodowych, Warszawa 1998, s. 24.

14 Idem, Problem sukcesji instytucjonalnej i dóbr przemieszçonych w wyniku żmiany granic, [w:] Dobra kultury i problemy wtasności. Doświadczenia Europy Środkowej po 1989 r., pod red. G. Czubek, P. Kosiewskiego, Warszawa 2005, s. 180.

15 Szerzej zob. idem, Repatriacja, s. 25 i n.

16 Idem, Problem, s. 182.

17 Konwencja o ochronie dóbr kulturalnych w razie konfliktu zbrojnego wraz z Regulaminem wykonawczym do tej Konwencji oraz Protokół o ochronie dóbr kulturalnych w razie konfliktu zbrojnego, podpisane w Hadze dnia 14 maja 1954 r., Dz. U. 1957, nr 46, poz. 212.

18 S. A. Williams, The International and National Protection of Movable Cultural Property. A Comparative study, New York 1978, s. 52-53. 
niu dla kolejnych pokoleń, bez konieczności akcentowania jego trwałego związku z danym terytorium czy narodem, podzielana przez Johna $\mathrm{H}$. Merrymana. Uznaje ona wspólność dziedzictwa, lecz jako jej rdzeń wskazuje pewną wolność zabytku rozumiana jako wolność jego przemieszczania. Sformułowana w ten sposób, nie tylko nie utrudnia, ale wręcz popiera rozwój międzynarodowego rynku dzieł sztuki. W stałej opozycji do powyższych założeń pozostaje tzw. koncepcja nacjonalistyczna, opierająca się na fakcie przynależności obiektu do określonego dziedzictwa narodowego $^{19}$. Trzeba dodać, że ustalenie składników patrimoine culturel danego kraju może odbywać się według różnych kryteriów, np. określonego terytorium, granicznego wydarzenia historycznego czy nawet pochodzenia twórców dzieł sztuki - zabytków. Wypada zaznaczyć, że koncepcje te nie nawiązuja bezpośrednio do problematyki repatriacji i dyplomatycznych sposobów rozwiązywania spraw w tym zakresie. Jednakże w jakimś stopniu pozwalają uzasadnić przynależność obiektu do danego terytorium i pozostawienie go w oryginalnym środowisku historycznym (o ile zostanie otoczone właściwą opieką przez nowego sukcesora) albo słuszność przeniesienia do innego kraju ze względu na istotne znaczenie dla tamtejszego dziedzictwa narodowego. W konsekwencji większość dotychczasowych traktatów międzynarodowych w dużej mierze opiera się na tych argumentach.

Niniejszy artykuł miał jedynie na celu przybliżenie historii kolekcji Bolesława Orzechowicza. Zagadnienie to zajmuje bardzo ważne miejsce w dyskusji o pochodzeniu zabytków i poszukiwaniu odpowiedzi na pytanie o właściwe miejsce ich położenia. Zasygnalizowanie czynników, które mogłyby mieć wpływ na byt prawny zbiorów, ukazuje, że istniejące konstrukcje własności zabytków nigdy nie występują w tzw. postaci czystej. Możliwość ich zastosowania pojawia się dopiero po ustaleniu możliwych okoliczności pobocznych, także mogących determinować rozwiązanie. Wśród nich należy z pewnością wymienić zmiany granic, w które historia Europy jest bardzo bogata. Sprawa zbiorów Orzechowicza ma współcześnie wymiar międzynarodowy i doskonale obrazuje problemy prawne związane z dziełami sztuki i zabytkami. Niewątpliwie osoba Bolesława Orzechowicza może być uznana za symbol pionierskiej, prywatnej

19 Szerzej zob. J. H. Merryman, Thinking about the Elgin Marbles, Critical Essays on Cultural Property, Art and Law, Hague-London-Boston 2000, s. 52-62. 
inicjatywy wspierania nauki i kultury polskiej w okresie międzywojennym, a jego nazwisko powinno być wymieniane obok innych znanych mecenasów sztuki. W naszym przekonaniu nieodżałowany pozostaje fakt, że wola darczyńcy, który już za życia został doceniony za swe zasługi i określany mianem „pomnożyciela kultury polskiej”, nie została w całości spełniona po jego śmierci, a wyraźny zapis w umowie darowizny, mający ochronić polskość kolekcji przed zdarzeniami przyszłości, niewykorzystany.

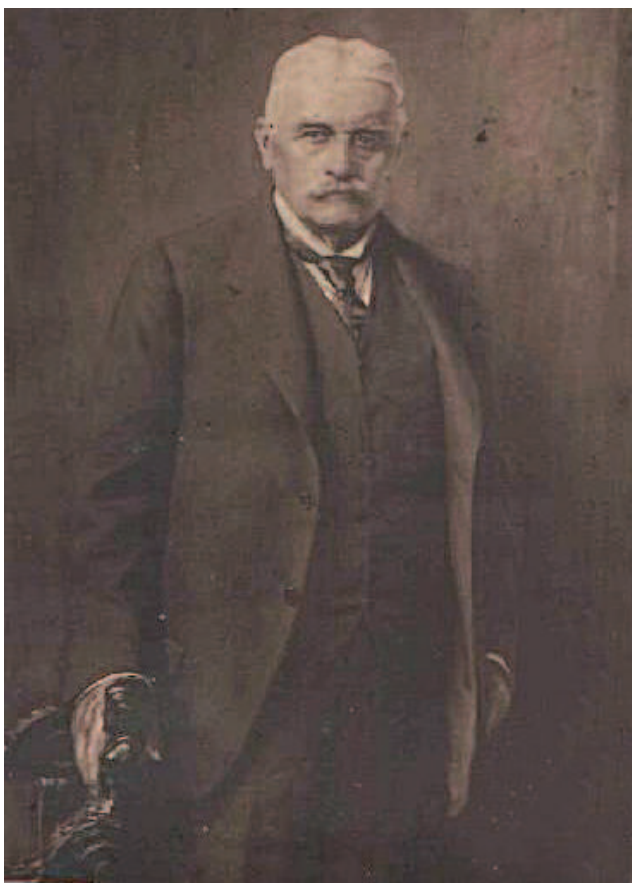

Il. 1. Bolesław Orzechowicz (1847-1927), za: www.wrota.podkarpacie 


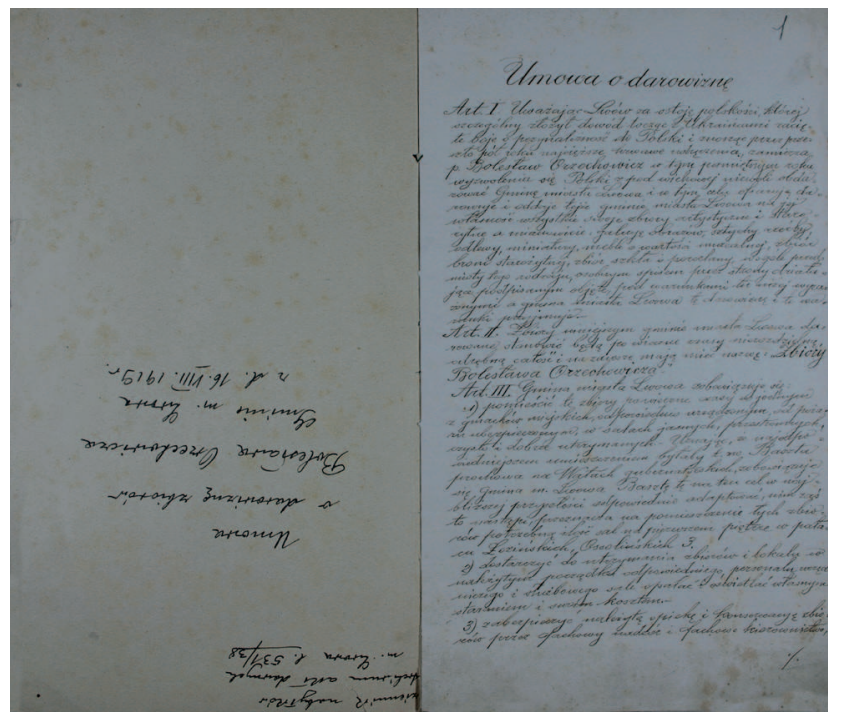

Il. 2. Umowa o darowiznę z dnia 16 sierpnia 1919 r., Centralne Państwowe Archiwum Historyczne Ukrainy we Lwowie, zespół 74, opis 1, jednostka 1, k. 1-2

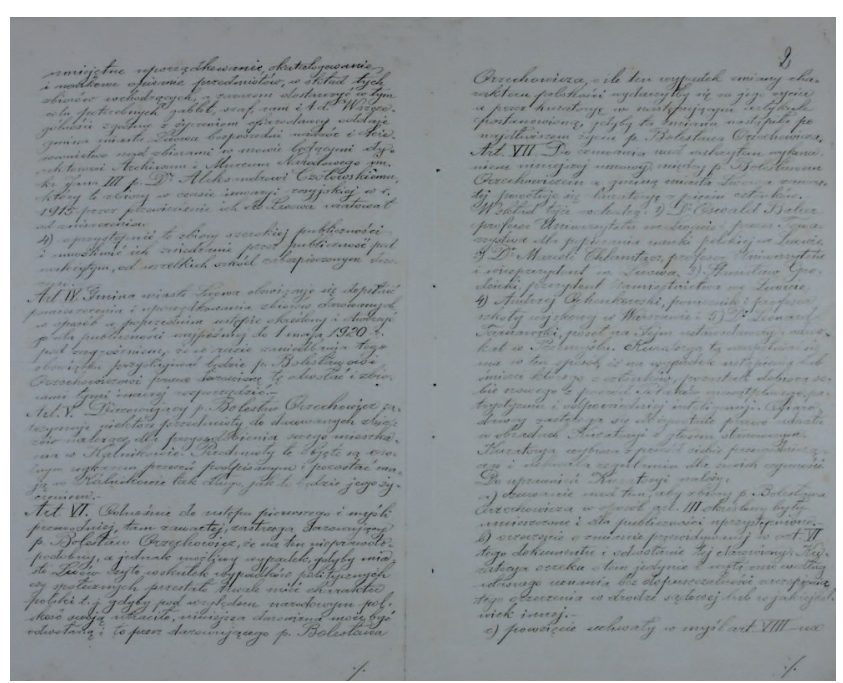

Il. 3. Umowa o darowiznę z dnia 16 sierpnia 1919 r., Centralne Państwowe Archiwum Historyczne Ukrainy we Lwowie, zespół 74, opis 1 , jednostka 1, k. 1-2 


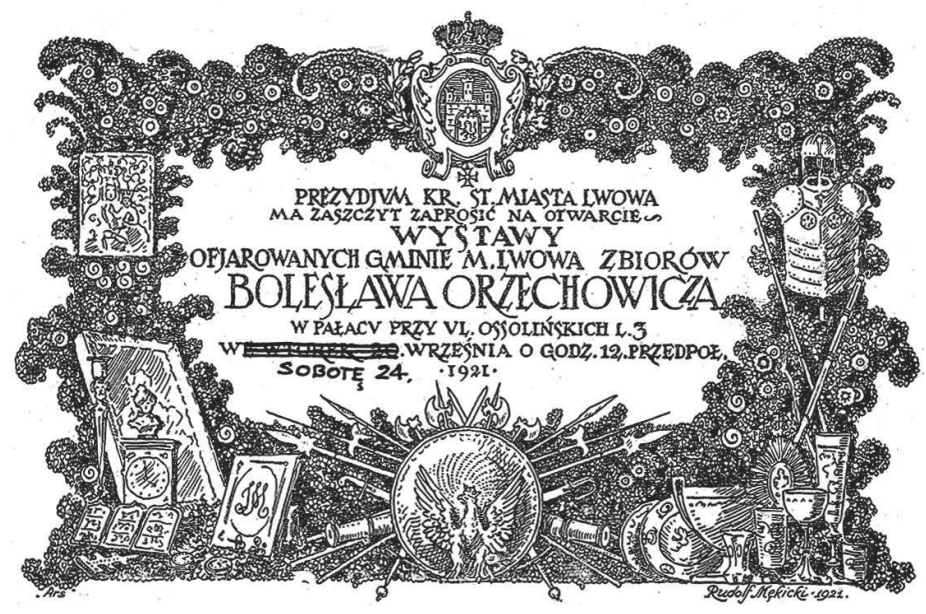

Il. 4. Zaproszenie na wystawę z okazji ofiarowania zbiorów (projekt autorstwa Rudolfa Mękickiego), Centralne Państwowe Archiwum Historyczne Ukrainy we Lwowie, zespół 74, opis 1, jednostka 5, k. 33

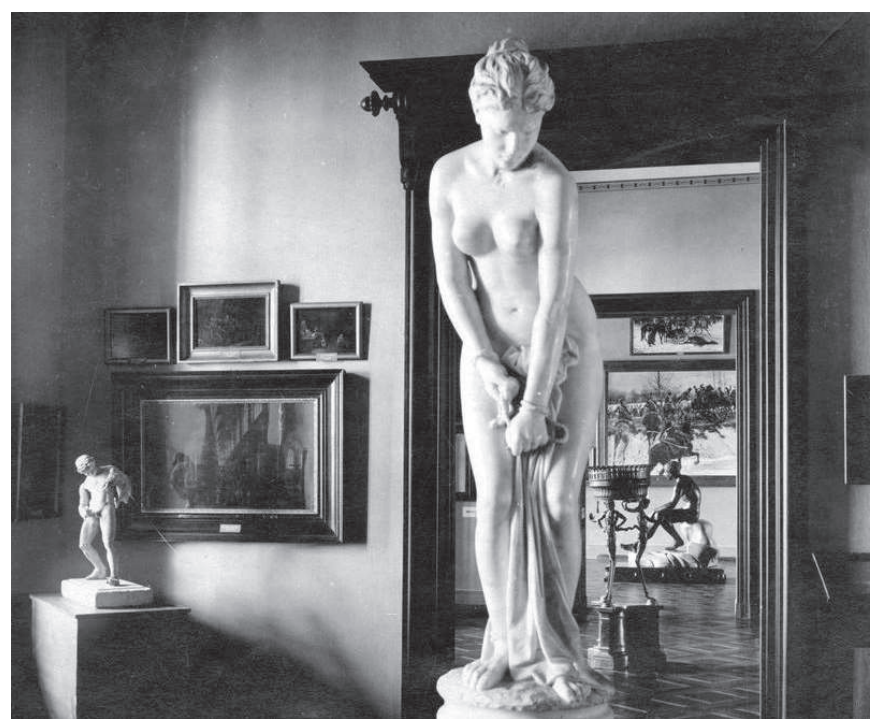

Il. 5. Sala IX z marmurowym posagiem Niewolnicy oraz zbiorami malarstwa obcego, za: K. Badecki, Zbiory Bolestawa Orzechowicza, Lwów 1922, tablica XXVII, s. 69 


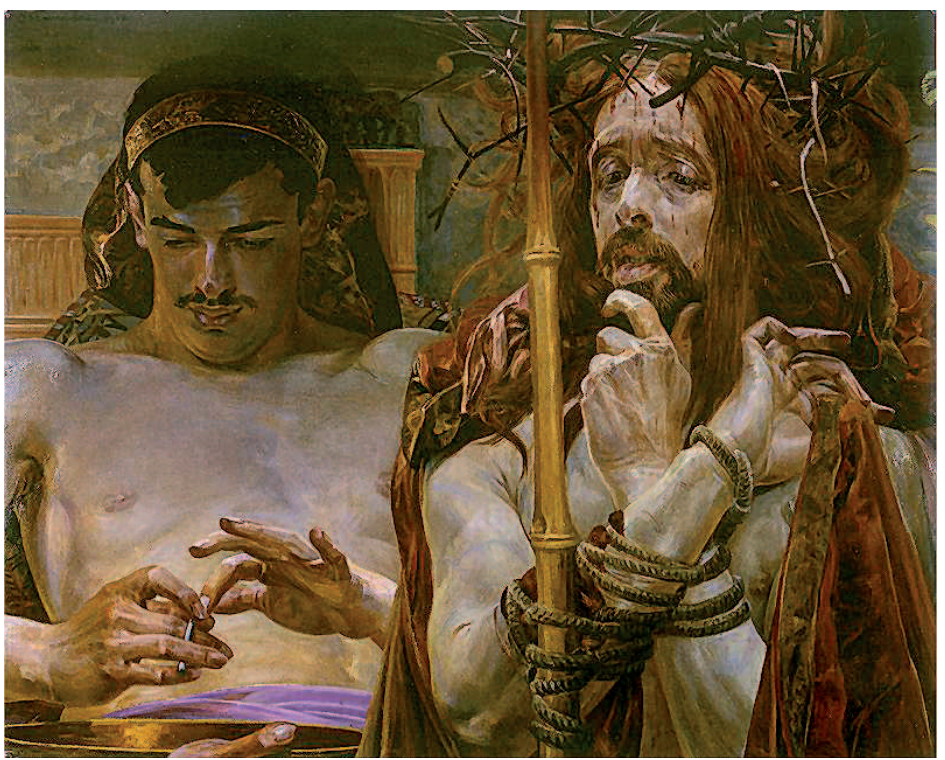

Il. 6. Jacek Malczewski, Chrystus przed Piłatem, 1910 r., Lwowska Galeria Sztuki (ze zbiorów B. Orzechowicza)

\section{Summary}

\section{Intricate case about the collection of works of art owned by Bolesław Orzechowicz in Lviv}

The article presents the life of Bolesław Orzechowicz (1847-1927), a man who devoted his life to art and science. His merits for the society were recognized by granting title of doctor honoris causa of Jan Kazimierz University and status citizen of honour of Lviv. Among his main achievements should be mentioned finacial support for Polish scientists and a donation of the valuable art collection for the city of Lviv. The modern theories concerning legal cultural heritage protection were described in the light of the created by Bolesław Orzechowicz collection's history. Analysed case confirms, that there are three legal spheres (public, private and internatonal), which determine the legal status of the cultural property. This leads to a conclusion, that the future EU, national or international legislator have to take into account, that every new legal solution have to fit them all. 